\title{
Ogled i odjek zaštite i sigurnije budućnosti djeteta u svjetlu Panamske i Rimske deklaracije
}

\author{
JoSIP BOŠNJAKOVIĆ* - LEALI OSMANČEVIĆ** \\ • https://doi.org/10.31823/d.29.2.5 • \\ UDK: $159.922 .7^{*} 342.7-053.2$ • Izvorni znanstveni rad \\ Primljeno: 3. kolovoza 2020. • Prihvaćeno: 27. svibnja 2021.
}

${ }^{*}$ Doc. dr. sc. Josip Bošnjaković, Katolički bogoslovni fakultet u Đakovu Sveučilišta

J. J. Strossmayera

u Osijeku, Petra

Preradovića 17,

p.p. 54, 31400

Đakovo, Hrvatska -

Hrvatsko katoličko sveučilište, Ilica 242, 10000 Zagreb,

Hrvatska, josip.

bosnjakovic@djkbf.hr

** Leali Osmančević, mag. comm.,

Hrvatsko katoličko sveučilište, Ilica 242,

10000 Zagreb, Hrvatska,

leali.osmancevic@ unicath.hr

Sažetak: Djeca i dječja prava iznimno su važna tema u znanstveno-istraživačkom te praktičnom području komunikologije, psihologije i teoloških razmatranja. Ta tema u središtu je sveopće službe vjerskih i medunarodnih institucija te udruga dok se zakonodavno-pravni okviri kreiraju svake godine štiteći djecu $i$ općeniti bitak u svijetu zagovarajući jednakost. Tako su 2017. godine prihvaćene dvije vrlo važne deklaracije: Panamska $i$ Rimska. U radu će se tema djeteta $i$ dječjih prava obraditi u svjetlu komunikologije, teologije i psihologije, kao i relevantnih dokumenata te će se analizirati i različiti pristupi navedenih deklaracija. Doprinos ovoga rada jest sveobuhvatni prikaz teme dječjih prava kroz prizmu navedenih deklaracija, što je ujedno i prva analiza tih dviju deklaracija koje štite dječja prava i dostojanstvo, kao i sigurniju budućnost na međunarodnoj razini.

Ključne riječi: djeca, dostojanstvo, zaštita, Panamska deklaracija, Rimska deklaracija, dječja prava.

\section{Uvod}

Dobrobit djece često se podrazumijeva zbog njihove ranjivosti i brojnih inicijativa za zaštitu njihovih prava, no u društvenoj i virtualnoj stvarnosti djeca su nerijetko objekti u negativnom kontekstu poput iskorištavanja, zloupotrebe, interesne skupine zarade, prodaje, preprodaje, zanemarivanja, otuđenja te ubojstava fizičkoga, psihičkoga, materijalnoga i duhovnoga stanja. U Hrvatskoj je dosad toliko učinkovitoga napravljeno zahvaljujući različitim instituci- 
jama, no ponajviše ovdje želimo spomenuti Polikliniku za zaštitu djece i mladih grada Zagreba koja kontinuiranim publikacijama, istraživanjima, umrežavanjem $s$ ostalim stručnjacima i sustavnom pomoći djeci i mladima na svim razinama djeluje i sudjeluje u promjenama, apelima i mijenjanju određenih stavova, ali i u širem kontekstu, svojevrsnim politikama u području zaštite djece i mladih, potom Katoličku Crkvu, ostale vjeroispovijesti i religije koje svojim radom, bilo humanitarnim, preventivnim ili konkretnom pomoći, utječu na javno mnijenje te na široj društvenoj razini kreiranjem i usvajanjem dokumenata sustavno obrazuju javnost $i$ istovremeno štite djecu i dječja prava, kao i različite udruge i nevladine organizacije kojima je dobrobit djece također jedan od prioriteta.

U Hrvatskoj je zasad gotovo nezapaženo prošla informacija o dvjema deklaracijama sa svjetskim odjekom, obje govore o zaštiti i dobrobiti djece. Prva je Panamska deklaracija o svršetku nasilja protiv djece donesena u Panami 11. svibnja 2017. godine, a druga je Rimska deklaracija sa Svjetskoga kongresa Dostojanstvo djece $u$ digitalnom svijetu, održanoga u Rimu od 3. do 6. listopada 2017. godine. Deklaracija je predstavljena tijekom audijencije s papom Franjom 6. listopada 2017. godine. Informativna katolička agencija objavila je 9. lipnja 2020. prijevod obiju deklaracija na hrvatski jezik. U ovom radu bit će predstavljene obje deklaracije i analize njihovih različitih pristupa o međunarodno značajnoj temi zaštite djece, ali će ponajprije biti definirano dijete i njegova uloga u svijetu. Nakon analize i doprinosa deklaracija, u radu će biti spomenuti i drugi međunarodni važni dokumenti i institucije povezane sa zaštitom dječjih prava te će još jedan od naglasaka biti stavljen na dostojanstvo djece kao zasebnu temu u području dječjih prava.

Uz navedeno, u radu će se kroz više dimenzija promatrati i definirati što sve podrazumijeva iskorištavanje djece, kao i otuđenje, što su ujedno i poticaji za još veće osvješćivanje društva i poziv za djelovanje i na lokalnim i na globalnim razinama. Cilj je rada tu temu i sadržaj deklaracija prikazati kroz tri prizme, odnosno sa stajališta triju vrlo važnih znanosti koje se bave upravo tim pitanjima, a to su komunikologija, psihologija i teologija.

\section{1. Što je i tko je dijete?}

Čovjek je stvoren na sliku Božju (Post 1,26). Papa Franjo pita može li se naći snažnija izjava o ljudskom dostojanstvu. Papinsko vijeće za Bibliju na čelu s kardinalom Ladarijom izdalo je 2019. godine dokument s naslovom Śto je čovjek? želeći u

\footnotetext{
${ }^{1}$ FRANJO, Govor pape Franje sudionicima kongresa $\gg$ Dostojanstvo djece u digitalnom svijetu $<$, svibanj 2017. Dostupno na: http://www.vatican.va/content/francesco/en/speeches/2019/november / documents/papa-francesco_20191114_convegno-child\%20dignity.html (6. 7. 2020.).
} 
suvremenome svijetu, na tragu i temelju Svetoga pisma, Staroga i Novoga zavjeta, odgovoriti na to uvijek aktualno pitanje. Unatoč očitom napretku na području tehnologije i neprestanom otkrivanju učinkovitih postignuća, što oplemenjuje naše društvo, svakom je pak pozornom promatraču također očito kako današnje društvo prolazi kroz duhovnu krizu. ${ }^{2}$ Zasigurno ono u čemu će se sve znanosti složiti jest da je čovjek, a time ujedno i dijete, relacijsko biće, te ćemo se za svrhu ovoga članka zaustaviti na toj dimenziji čovjeka, odnosno djeteta. Na Svjetskom kongresu Dostojanstvo djeteta u digitalnom svijetu kardinal Tagle u svom predavanju ${ }^{3}$ pozvao je sudionike kongresa na odgovor na pitanje danas: Tko/Što je dijete? Stoga je značajno primijetiti kako je prva rečenica Rimske deklaracije ${ }^{4}$ sljedeća: »Život svakog djeteta je jedinstven, značajan i dragocjen i svako dijete ima pravo na dostojanstvo i sigurnost.«

U kršćanskoj antropologiji prepoznaje se i ispovijeda utjelovljenje Isusa po Djevici Mariji i slavi se njegovo rođenje, rođenje djeteta u Betlehemu. Dijete, kao i svako drugo ljudsko biće, neponovljivi je znak Božje ljubavi i Božje prisutnosti među nama. Bog se rodio kao nemoćno Dijete i u tome, iako samom razumu nedokučivo, ali ne i protivno razumu, Bog pokazuje povjerenje povjerivši Mariji i Josipu dijete Isusa da odrasta u njihovoj obitelji. Dijete je dar, a oni koji ga dobiju obdareni su te time ujedno i obogaćeni. Međutim i prije rođenja Isusa u Betlehemu, kao i tik nakon njegova rođenja, postojala je opasnost da će njegov život uništiti moćnici kao što je to bio i Herod (Mt 2, 16-19). Kasper u knjizi Milosrđe piše kako smo u 21. stoljeću ugroženi nemilosrdnim terorizmom i nepravdom koja vapi u nebo te da se zlorabe i izgladnjuju djeca, no dodali bismo ne samo da se izgladnjuju djeca nego se koriste kao sredstvo zarade, gdje djeca postaju objekti pojedinih zlonamjernih skupina odraslih ljudi, zaslijepljenih za ljepotu života, koje uništavaju živote mnoge djece. $^{5}$

U Panamskoj deklaraciji ${ }^{6}$ izričito se i spominje kako se svakih pet minuta u svijetu ubije jedno dijete. Stoga i danas, još žurnije, ostaje poziv evanđelja, radosne vijesti, Isusa Krista, kako nam prenosi evanđelist Matej 18, 1-5:

${ }^{2}$ PAPINSKO VIJEĆE ZA BIBLIJU / PONTIFICIA COMMISSIONE BIBLICA, Che cosa è l'uomo. Un itinerario di antropologia biblica, Città del Vaticano, 2019.

${ }^{3}$ L. A. TAGLE, Challenges to and Means for effective Cooperation in Safeguarding of Minors in the Developing World. The Asian Perspective, Child Dignitiy in the Digital World, Rim, 5. 10. 2017.

${ }^{4}$ Rimska deklaracija. Dostupno na: https://ika.hkm.hr/dokumenti/rimska-deklaracija/ (6. 7. 2020.).

${ }^{5}$ W. KASPER, Milosrđe. Temeljni pojam evanđelja - ključ kršćanskog života, Zagreb, 2015.

${ }^{6}$ Panamska deklaracija. Dostupno na: https://ika.hkm.hr/dokumenti/panamska-deklaracija/ (6. 7. 2020.). 
$\gg$ U onaj čas pristupe učenici Isusu pa ga zapitaju: ‘Tko je, dakle, najveći u kraljevstvu nebeskom?' On dozove dijete, postavi ga posred njih i reče: 'Zaista, kažem vam, ako se ne obratite i ne postanete kao djeca, nećete ući u kraljevstvo nebesko. Tko god se dakle ponizi kao ovo dijete, taj je najveći u kraljevstvu nebeskom. I tko primi jedno ovakvo dijete u moje ime, mene prima', $\ll$

Staviti u središte dijete i djetetove potrebe, ali i njegove karakteristike, put je kojim je i danas izazovno hodati. Isus za mjerilo ulaska u kraljevstvo nebesko postavlja dijete. Koje su karakteristike djeteta? Sliku djeteta izvrsno nam donosi evanđelist Ivan $(6,9)$ kada jedan dječak, u situaciji gladi, stavlja na raspolaganje zajednici pet kruhova i dvije ribe, što daje broj sedam. Broj sedam u Svetome pismu označava potpunost. Dakle taj dječak za potrebe društva daje sve što mu je na raspolaganju. Upravo je suprotna logika zlostavljanja djece, odnosno uzimanja svega od njih za vlastite potrebe, a među ostalim, oduzimanja gotovo i njihova života, te mnoga zlostavljana djeca nastavljaju živjeti svoje živote, često s osjećajem bezgraničnoga tereta i neizmjerne težine na njihovim leđima, srcima, razumu. Oduzet im je život $i$ često hodaju kroz život beživotni.

Bauer$^{7}$, pišući o rastu djeteta, ali i načelno svih ljudi, navodi tri preduvjeta. Prvi je postizanje autonomije (koja, naravno, uključuje međuljudsku ovisnost) što znači uvažavati već poznate i utabane staze, ali ujedno i otkrivati nove mogućnosti postojanja. To zahtijeva hrabrost i odvažnost suočavati se s novim pitanjima i rizicima, a to je moguće kada je osoba svjesna svojega nutarnjega, božanskoga dostojanstva. Temeljna Bauerova teza jest da je čovjek rezonantno biće, odnosno odjek (ne jeka) stvarnosti u kojoj živi. Hoće li dijete biti svjesno vlastitoga dostojanstva prije svega ovisi o tome odnosi li se okolina prema njemu na takav način. Dakako da digitalni svijet danas nudi neizmjerne mogućnosti novih oblika postojanja i relacija, odjeka, ali to nužno uključuje i drugu karakteristiku koju navodi Bauer, ali i papa Franjo u predstavljanju Rimske deklaracije, a to je postavljanje granica. Dijete je ovisno o drugima, ono je ograničeno biće. Sama riječ ograničen naznačuje kako je riječ o granicama. Odrediti granicu dopuštenoga, mogućega jedno je od temeljnih načela i zdravoga odgoja. Većina žrtava, odnosno pogođenih osoba, susreću se s problemom poštovanja svojih ili tuđih granica jer su tako bolno na svom putu odrastanja iskusili teško nepoštovanje granica. Tim više što dijete uči poštovati granice učeći od odraslih. Treći preduvjet jest potreba djeteta za mentorom/icom koji će dijete ohrabriti na vlastitom putu odrastanja. ${ }^{8}$ Nije potrebno dalje tumačiti koliko upravo

\footnotetext{
${ }^{7}$ Usp. J. BAUER, Wie wir werden, wer wir sind. Die Entstehung des menschlichen Selbst durch Resonaz, München, Blessin, 2019.

${ }^{8}$ Usp. isto, 53.
} 
ta dimenzija izostaje u slučajevima nasilja nad djecom. Djeca imaju pravo na život, odrastanje i odgoj bez nasilja u bilo kojem obliku, pri čemu se ne misli samo na zlostavljanje kao krajnje štetno djelovanje za dijete, koje se sankcionira i zakonom, nego i na manje očite oblike nasilja kao što su pretjerano kontroliranje, oštro i neosjetljivo kažnjavanje itd. ${ }^{9}$

\section{2. Četiri relacijska pristupa odrastanju djeteta}

Već smo spomenuli kako među različitim obilježjima ljudskoga bića želimo naglasiti relacijsku stvarnost svakoga živoga bića. Na tragu toga spomenut ćemo četiri teoretska pristupa u psihologiji koja su naglašavala upravo tu karakteristiku te nakon toga u kratkim crtama protumačiti pojam otuđenosti jer je danas zbog učestalijih rastava sve prisutnija stvarnost otuđenja kod djece, a upravo je i ono relacijske prirode i dovodi do dodatnih poteškoća u odgoju djece, kao i njihovoj zaštiti. Među prvima želimo spomenuti Sigmunda Freuda, kao i pionire psihodinamskoga pristupa u psihologiji kao što su A. Freud, M. Mahler, J. Sandler, M. Klein, M. Balint, W. Bion, R. Fairbairn, S. W. Winnicott i ostali koji su vrlo jasno istaknuli važnost relacije u nastanku ljudskoga bića, s posebnim naglaskom na prve godine života. Već spomenuti neuroznanstvenik Bauer ${ }^{10}$ na vrlo sličan način ističe važnost prvih godina života za zdrav rast ljudske osobe, a time se vraćamo i na načelo good enough mother ${ }^{11}$, odnosno načelo prema kojem je za povoljan rast djeteta potrebno imati dovoljno dobru mamu i dovoljno dobroga tatu, to jest dovoljno dobre roditelje. Nisu potrebni idealni, nego dovoljno dobri skrbnici.

Drugi relacijski pristup jest psihosocijalna teorija razvoja prema E. Eriksonu. Prema Eriksonovoj teoriji svaki čovjek prolazi kroz osam psihosocijalnih kriza te uspješnim nadvladavanjem istih sazrijeva kao osobnost te stječe određenu vrlinu karakterističnu za određenu dob. Mi ćemo za potrebe ovoga rada istaknuti prve četiri vrline, a to su povjerenje (stječe se do 18 mjeseci života), autonomija (između 18 mjeseci i treće godine života), inicijativa (između treće i šeste godine života) te kompetentnost (između šeste i dvanaeste godine života). U odnosu s drugima dijete raste u sigurnosti i stječe povjerenje, zatim kroz podršku drugih uči se autonomiji, potičući razvoj, ono je sposobno imati inicijativu (ponajprije u igri), a zatim u suodnosu s vršnjacima razvije različite kompetencije. Ako tijekom razvoja dođe

\footnotetext{
${ }^{9}$ G. BULJAN FLANDER i suradnici, Znanost i umjetnost odgoja - Praktični priručnik o suvremenom odgoju za roditelje i odgojitelje, Sveta Nedjelja, 2018., 24.

${ }^{10} \mathrm{~J}$. BAUER, Wie wir werden, wer wir sind.

${ }^{11}$ G. GABBARD, Psychotherapeutic Treatmants, Washington, 2009.; A. LIS, S. STELLA, G. ZAVATTINI, Manuale di psicologia dinamica, Milano, 1999.
} 
do težih trauma, tada je i oporavak za jedno dijete, odnosno odrasloga čovjeka, dugotrajniji. ${ }^{12}$

Treći pristup koji ovdje želimo spomenuti jest interpersonalni pristup L. S. Benjamin. Tri su procesa prema Benjamin pomoću kojih dijete sazrijeva prema zreloj osobnosti. To su identifikacija, introjekcija i rekapitulacija. Proces identifikacije jest oblik dugotrajne imitacije roditeljsko-skrbničkih figura, odnosno dijete će vrlo vjerojatno djelovati poput ljudi koji su mu važni. Na primjer, ako dijete odraste u kući punoj krivice, velika je vjerojatnost da će postati osoba koja krivi, a ako odrasta u kući punoj poštovanja, velika je vjerojatnost da će postati osoba koja poštuje sebe i druge..$^{13} \mathrm{U}$ procesu introjekcije osoba se odnosi prema sebi na isti način na koji su se prema njoj odnosile važne osobe. ${ }^{14} \mathrm{Na}$ primjer djevojčica odgajana u vrlo zanemarujućem ili otuđujućem okruženju vrlo vjerojatno imat će tendenciju zanemarivati sebe. Ako se nitko nije pobrinuo za nju, ne će se ni ona sama pobrinuti za sebe. Kod procesa rekapitulacije mentalne reprezentacije važnih ljudi postaju dio nutarnjih reprezentacija samih osoba. Unutar svoga uma pojedinac se odnosi prema mentalnim reprezentacijama (predstavljanjima/zamišljanjima) važnih osoba kao da je to interakcija sa živim osobama. Na primjer dijete koje razmišlja da uzme nož može čuti oca kako kaže ne i podvrgava se tom sjećanju. Dječak prilazi kuhinjskom stolu, ali ne uzima nož jer reagira na internalizaciju svoga oca. Benjamin ističe kako svaka osoba ima Gift of Love (GOL), dar ljubavi, koji je dobila u ozračju odrastanja, s time da taj dar može imati vrlo različite sadržaje, odnosno netko je naučio da ljubav i nasilje idu zajedno, dok su drugi naučili da ljubav i poštovanje idu zajedno. Osim toga Benjamin također piše kako svaka osoba sa sobom nosi Family in the Head, odnosno obitelj u glavi. To je posljedica triju opisanih procesa s kojima nastavljamo živjeti i kada se odmaknemo iz konteksta odrastanja iz prvih godina života. ${ }^{15}$

Četvrti psihološki pristup relacijskom sazrijevanju osobe jest pristup transakcijske analize. ${ }^{16}$ Prema tom pristupu svaka osoba razvija u odnosu s drugim osobama tri ego stanja, a to su ego stanje roditelj, ego stanje odrasli te ego stanje dijete. Sva tri ego stanja sastavni su dio cjeloživotne dinamike jedne osobe te za autonomno funkcioniranje u životu potrebno je da osoba osjeća, misli i djeluje iz svih triju ego stanja,

\footnotetext{
${ }^{12}$ E. ERIKSON, Identitet $i$ životni ciklus, Beograd, 2008.

${ }^{13}$ L. S. BENJAMIN, Terapia ricostruttiva interpersonale. Promuovere il cambiamento in coloro che non reagiscono, Roma, 2014.

${ }^{14}$ H. S. SULLIVAN, The interpersonal theory of psychiatry, New York, 1953.; S. STAHL, Das Kind in dir muss Heimat finden, München, 2015.

${ }^{15}$ L. S. BENJAMIN, Terapia ricostruttiva interpersonale, 159-160.

${ }^{16}$ E. BERNE, Intuizione e Stati dell'Io, Astrolabio, Roma, 2012.; E. BERNE, »Ciao! « ... E poi?, Milano, 2008.; J. STEWART, V. JOINES, A New Indroduction to Transactional Analysis, New Barn, 2012.
} 
ovisno o okolnostima u kojima se nađe. Zbog raznih, težih ili blažih, poteškoća odrastanja može se dogoditi da osoba jedno ili dva ego stanja na svojevrstan način zanemari, potisne, zaboravi, ignorira, što pak utječe na kvalitetu života. Tijekom zlostavljanja, zanemarivanja ili otuđenja veća je vjerojatnost ranjivosti ego stanja djeteta. Potreban je dugotrajan proces ponovnoga revitaliziranja do kojega može doći ako se osoba susretne s okruženjem koje iskazuje uvažavanje, poštovanje, ljubav, pažnju i brigu te nastavi živjeti u tom okruženju. Na tragu navedenih pristupa u psihologiji također uviđamo snažnu potrebu integriranja i oživljavanja načela $\mathrm{Pa}-$ namske i Rimske deklaracije.

Kao što smo spomenuli na početku ovoga dijela rada, želimo kratko pojasniti problematiku otuđenja koja je sve prisutnija u odnosima između roditelja i djece te koja dodatno utječe na zanemarivanje i zlostavljanje djece, a uključuje prije svega relacijske čimbenike. Naime Buljan Flander i Roje Đapić ${ }^{17}$, referirajući se na Kru$\mathrm{ka}^{18}$, navode sljedeću definiciju otuđenja: Djeca mogu biti manipulirana od strane jednog roditelja kako bi odbacila drugog roditelja koji ne zaslužuje odbacivanje. ${ }^{19}$ O pojmu otuđenja počelo se govoriti 40-ih godina prošloga stoljeća, no danas se pomoću PASG-a (Parental Alienation Study Group) ${ }^{20}$, kao i drugih organizacija i institucija, sve više govori o temi otuđenja. Govoriti o temi otuđenja znači proučavati taj proces iz interdisciplinarnoga kuta promatranja te također uz podršku zakonskih normi i pravila ${ }^{21}$. Svjesni smo kako se najveći broj zlostavljanja djece događa unutar obitelji, stoga je iznimno važno na stručan i znanstven način razumijevati procese otuđenja kako bi se zaštitila dobrobit djece i njihovo dostojanstvo. Sve je učestaliji fenomen u našem društvu da je dijete u procesu svoga odgoja usmjereno na oba roditelja koji pak žive razdvojeni, odnosno koji su rastavljeni. Ta činjenica postavlja dodatne izazove za odgoj djece, a od stručnjaka traži dodatne napore u pružanju podrške razdvojenim roditeljima kako bi dijete raslo u sigurnim i mirnim uvjetima. To uključuje poznavanje funkcioniranja proširenih sistema obitelji kako bi se na najbolji mogući način osigurao razvoj djeteta koji će promicati njegovu dobrobit, kao i dobrobit roditelja. Svaki je roditelj resurs za svoje dijete, no roditelj se prije svega treba suočiti sa svojim poteškoćama i problematikom kako ne bi

${ }^{17}$ G. BULJAN FLANDER, M. ROJE ĐAPIĆ, Dijete u središtu (sukoba), Sveta Nedelja, 2020.

${ }^{18}$ E. KRUK, Arguments Against a Presumption of Shared Physical Custody in Family Law, u: Journal of Divorce \& Remmarigae 59(2018.)5, 388-400.

${ }^{19}$ Isto, 44.

${ }^{20}$ https://pasg.info/ (16. 1.2021.).

${ }^{21}$ R. J. JOHNSTON, J. M. SULLIVAN, Parental Alienation: In Search of Common Ground For a More Differentiated Theory, u: Family Court Review 58(2020.)2, 270-292. 
opterećivao dijete svojim problemima. ${ }^{22}$ To je dugotrajan proces koji podrazumijeva suradnju raznih sustava, počevši od obitelji, vrtića, škole, Centara za socijalnu skrb, institucija koje se posvećuju rastu i dobrobiti djece, Crkve i ostalih. Uza sve poteškoće kroz koje dijete prolazi, ono, kao i svako drugo živo biće, jest prije svega relacijsko biće koje ponajprije uči kako se odnositi prema drugima, uči od svojih primarnih figura kako vrjednovati vlastito dostojanstvo.

\section{Djeca i dječja prava}

Dijete je dio najosjetljivije i često najranjivije skupine društva, posebice u kriznim situacijama, ali i zbog pojave da ih se često doživljava kao nedovoljno podobne za izražavanje mišljenja. Tako se i u znanosti stvorio fenomen pisanja o djeci bez dječjega mišljenja i glasa, kao i u medijima u kojima se mogu pronaći brojni prilozi o djeci i za djecu važnim temama, a koji ne podrazumijevaju dječje sudjelovanje. ${ }^{23}$ Prema članku 1. Konvencije o pravima djeteta (1989.), dijete je svako ljudsko biće i osoba do navršenih 18 godina života, odnosno punoljetstva, dok prema zakonodavno-pravnim okvirima postoji i podjela na mlađe i starije maloljetnike, odnosno populaciju djece u dobi adolescencije. U kontekstu komunikologije kao interdisciplinarne znanosti i neizostavnih sredstava masovne komunikacije, odnosno medija, djeca imaju pravo na pristup medijima, sudjelovanje u stvaranju medijskih sadržaja i jednaku zastupljenost kao i sve druge društvene skupine. ${ }^{24}$ Djeca su također i zasebna medijska publika pa u skladu s tim i primatelji različitih medijskih sadržaja koji na njih mogu imati dva temeljna utjecaja - prije svega na njihovu samopercepciju vezanu uz medijske sadržaje o svojim vršnjacima, kao i na stav i mišljenje odraslih o djeci, također na temelju medijskoga portretiranja djece i tema vezanih uz njih. ${ }^{25}$

Djeca i dječja prava česta su i gotovo neizostavna tema brojnih znanstvenih istraživanja, stručnih radova te profesionalnih djelovanja u lokalnim i globalnim zajednicama. Također su upravo djeca i dječja prava te njihova zaštita povod za osmišljava-

${ }^{22}$ G. BULJAN FLANDER, M. ROJE ĐAPIĆ, Dijete u središtu (sukoba).

${ }^{23}$ L. CIBOCI, L. OSMANČEVIĆ, Percepcija učenika osmih razreda o prikazu djece i njihovih prava u hrvatskim medijima, u: V. CAR, M. MATOVIĆ (ur.), Mediji, novinarstvo i ljudska prava, Zagreb, 2017.; B. FRANKLIN, Children's rights and media wrongs. The new handbook of children's rights: Comparative policy and practice, 2002.; N. ZGRABLJIĆ ROTAR, Pravo na privatnost: standardi za zaštitu prava djece u medijima, u: M. FLEGO (ur.), Zaštita privatnosti djece u medijima, Zbornik priopćenja s tribine, Zagreb, 2009., 33-44.

${ }^{24}$ B. KOLUCKI, D. LEMISH, Kako komunicirati s djecom. Načela i prakse za podršku, nadahnuće, poticaj, obrazovanje i iscjeljenje, Zagreb, 2013.

${ }^{25}$ L. OSMANČEVIĆ. Zaštita dječjih prava u humanitarnim akcijama s osvrtom na afričke zemlje, u: Medijske studije/Media Studies 9(2018.) 18, 44-58. 
nje i provođenje različitih projekata i inicijativa koje ujedno i osvještavaju javnost o važnosti te teme. Tomu u prilog mogu se pridodati i brojni zakonodavni i pravni te regulatorni akti, na čelu s Ustavom Republike Hrvatske, ali i brojni međunarodno priznati dokumenti, zakoni i konvencije koji se isključivo bave proučavanjem, istraživanjem, promoviranjem i zaštitom dječjih prava, kao i prevencijom nedovoljne zaštite spomenutih prava.

Nastojanja u zaštiti dječjih prava temelje se na jednoj vrlo jakoj motivaciji koja se odnosi na istraživanje ključnih tema i pitanja u području dječjih prava koja mogu imati utjecaj na promjenu i boljitak dječjih života. Taj oblik motivacije brzo se raširio među znanstveno-stručnom populacijom, unutar koje su nastali brojni novi prijedlozi za promjenu dosadašnjih politika potkrijepljenih i djelovanjem u praksi, a sve radi još kvalitetnije zaštite djece i njihovih prava. ${ }^{26} \mathrm{U}$ brojnim medijskim sadržajima i svim sadržajima koji govore o djeci na bilo koji način najrjeđe se mogu pronaći dječja mišljenja, izjave, stavovi, čak i kada je izravno o njima riječ. U tom području vidljiv je oksimoron s obzirom na to da je jedno od temeljnih dječjih prava upravo pravo djeteta na sudjelovanje. Dječja prava daju određenu slobodu djeci kako bi se mogla izraziti, sudjelovati i aktivno djelovati u svojoj okolini, ponajprije u obitelji, ali i bilo kojoj drugoj vrsti zajednice u kojoj žive i okolini unutar koje vrijeme provode $s$ vršnjacima, prije svega iznoseći svoje mišljenje. ${ }^{27}$

Kada je riječ o pravima i u tom kontekstu dječjem pravu na sudjelovanje, riječ je, zapravo, o sposobnosti koju osoba, a u ovom slučaju dijete, ima da nešto učini, zahtijeva i djeluje. Takozvana teorija moći, kada je riječ o pravima, povezuje se s razvijenim vještinama koje svaku osobu osposobljavaju na racionalno i aktivno djelovanje. ${ }^{28} \mathrm{Za}$ cjelokupan razvoj društva djetetova riječ i njegova uloga u zajednici vrlo su važne. Prema UN-ovoj Konvenciji o pravima djeteta, upravo je sudjelovanje vrlo naglašeno u području razvoja i napretka društva. Pravo na sudjelovanje uključuje djetetovu sposobnost za izražavanje mišljenja, ali i pravo na pristup informacijama relevantnim za njega i teme koje ga se tiču. ${ }^{29}$ Spomenutu Konvenciju o pravima djeteta UN je donio 1989. godine te je ona 2019. godine doživjela svojih 30 godina postojanja. Međunarodna organizacija UNICEF tom prilikom donijela je niz prijedloga za dodatnu zaštitu dječjih prava, posebice zbog brojnih promjena koje je donijelo 21. stoljeće. Slijedom navedenoga, UNICEF i UN i dalje snažno inzi-

${ }^{26}$ A. SMITH (ur.), Enhancing children's rights: Connecting research, policy and practice, Basingstoke, Hampshire, 2015., 4-5.

${ }^{27}$ H. KOSHER, A. BEN-ARIEH, What children think about their rights and their well-being: A cross-national comparison, u: American Journal of Orthopsychiatry 87(2017.)256, 2.

${ }^{28}$ L. VIVANCO, R. DELGADO-BOLTON, Encyclopedia of Global Bioethics, Pitsburgh, 2015., 3.

${ }^{29}$ M. JOHN, Children's rights and power: Charging up for a new century, London, 2003., 201-203. 
stiraju, s još više inicijativa i projekata, da uistinu svako dijete, bez obzira na bilo koju moguću različitost, ima jednaka prava, u svim uvjetima i u svim zemljama, s naglaskom na pravo o mirnom djetinjstvu, pravo na sudjelovanje i jednakost, bez obzira na uvjete odrastanja i druge različitosti vezane uz vjeru, nacionalnost, kulturu i slična identitetska obilježja. ${ }^{30}$ Tako je UNICEF primjerice 2015. godine proveo istraživanje i izdao publikaciju Teaching and learning about child rights: A study of implementation in 26 countries. U njoj je u suradnji s međunarodnim partnerima proveo niz studija slučaja u različitim zemljama te analizirao način poučavanja i učenja o dječjim pravima na svim obrazovnim razinama. Također UNICEF sustavno nudi i niz edukativnih tečajeva, kao što je Child rights and why they matter, koji su prilagođeni različitim dobnim skupinama. U dvogodišnjem projektu Speak Out on Children's Rights, with Outright!, započetom 2019. godine, provoditelji su nizom aktivnosti osnaživali prije svega djecu i mlade, a onda i odrasle, u uključivanju i izražavanju mišljenja djece i mladih o temama koje se tiču upravo njih te su ih poticali na aktivno sudjelovanje u svojoj okolini, ali i u stvaranju medijskih sadržaja.

Govoreći o dječjim pravima, vrijedno je spomenuti i dva govora pape Ivana Pavla II. Prvi je izrečen na Generalnoj skupštini Ujedinjenih naroda 2. listopada 1979. godine, gdje je, među ostalim, Papa rekao:

$\gg$ Želim ( ... ) izraziti radost koju za svakoga od nas predstavljaju djeca, proljeće života, predostvarenje buduće povijesti svake ovozemne domovine. Nijedna zemlja na svijetu, nijedan političku sustav ne može sanjati o svojoj budućnosti drukčije osim preko slike tih novih naraštaja koji će od svojih roditelja preuzeti mnogostruku baštinu vrjednota, dužnosti, nadahnuća naroda komu pripadaju, kao i baštinu cijele ljudske obitelji (... ). I stoga, što se može više poželjeti svakomu narodu, svoj djeci svijeta, ako ne tu sretniju budućnost kojoj će poštovanje prava čovjeka postati puna zbilja u 2000. godini koja se približava.« (FC, br. 26) ${ }^{31}$

Drugi govor papa Ivan Pavao II. održao je u povodu 29. Svjetskoga dana mira 1. siječnja 1996. godine. Bio je upućen cijelom svijetu te ga je posvetio upravo djeci u kontekstu uske povezanosti s postizanjem mira u svijetu. Taj govor i dokument iznimno je važan za razumijevanje dječjih prava i jednakosti djece te ujedinjenja svijeta u odnosu prema najmlađim članovima društva. U svom govoru Papa se

${ }^{30}$ UNICEF, dostupno na: https://www.unicef.org/child-rights-convention/global-action (8. 7.2020.).

${ }^{31}$ Usp. ADDRESS OF HIS HOLINESS JOHN PAUL II TO THE 34th GENERAL ASSEMBLY OF THE UNITED NATIONS, dostupno na: http://w2.vatican.va/content/john-paul-ii/en/ speeches/1979/october/documents/hf_jp-ii_spe_19791002_general-assembly-onu.html (8. 7 . 2020.). 
osvrnuo i na najranjivije skupine djece, odnosno onu djecu koja su u ratnim zonama te koja su žrtve bilo kojega oblika nasilja i zlostavljanja. Zaključno, istaknuo je da su djeca i odnos prema njima put do mira u cijelom svijetu i pozvao je sve da djeci daju jednaku budućnost koju je nazvao budućnost mira. ${ }^{32}$

\section{Struktura i sadržaj Panamske i Rimske deklaracije}

Panamska i Rimska deklaracija dva su iznimno važna dokumenta i doprinosa u zaštiti djece, njihovih prava i dostojanstva, kao i vrijedni pomaci u nastojanju osvješćivanja širih društvenih skupina, ali i autoriteta u javnosti koji djeluju u različitim područjima. Obje su donesene i usvojene 2017. godine, a po strukturi ih se može podijeliti na tri dijela, prvi, opći dio, drugi dio s posebnim točkama te treći s kraćim zaključkom. Pristup spomenutih deklaracija različit je, što je također bitan indikator $\mathrm{u}$ isticanju važnosti iste teme na više načina. Budući da je Panamska deklaracija izdana pet mjeseci prije u odnosu na Rimsku deklaraciju, našu ćemo pozornost usmjeriti prvo na nju.

\subsection{DinamiČni PRistup Panamske Deklaracije}

Arigatou International prepoznaje vitalnu ulogu koju vjerski vođe i njihove zajednice mogu imati u njegovanju zdravih vrijednosti i podržavanju pozitivnoga ponašanja u njihovim društvima. Da bi osigurao globalnu platformu za međureligijsku suradnju za djecu, Arigatou je u svibnju 2000. godine pokrenuo Globalnu mrežu religije za djecu (GNRC) na prvom globalnom forumu u Tokiju. $S$ globalnim forumima koji su se održavali u Ženevi 2004., Hirošimi 2008., Nairobiju 2012. i Panami 2017. GNRC je prerastao u široku međureligijsku mrežu vjerskih organizacija i ljudi vjere koji zajedno rade na pravima i dobrobiti djece šrom svijeta. ${ }^{33}$ Svojim djelovanjem postali su jedna od vodećih međunarodnih organizacija za zaštitu dječjih prava na svim razinama i zalaganje za jednakost u njihovim pravima i očuvanje dostojanstva u svim prilikama.

Panamska deklaracija (The Panama Declaration on Ending Violence Against Children) po svojoj strukturi i namjeri odgovara dinamičnom pristupu, u smislu da se razgovor o dobrobiti djece u svijetu kroz deset načela započinje glagolima: slušati djecu (1); osigurati kako bi religiozna mjesta bili sigurna za djecu (2); povećati osobna i institucionalna obećanja (3); odgajati lidere i zajednice (4); dogovarati

${ }^{32}$ Usp. MESSAGE OF HIS HOLINESS POPE JOHN PAUL II FOR THE XXIX WORLD DAY OF PEACE, 1996. Dostupno na: https://w2.vatican.va/content/john-paul-ii/en/messages/peace/ documents/hf_jp-ii_mes_08121995_xxix-world-day-for-peace.html (8.7.2020.).

${ }^{33}$ ARIGATOU INTERNATIONAL, dostupno na: https://arigatouinternational.org/en/who-weare (18.4.2020.). 
se (biti partner) s globalnim programima (5); ojačati lokalne zajednice (6); identificirati i dovesti u pitanje patrijarhalne strukture i prakse (7); prihvatiti međunarodno ugovorene strategije i mehanizme (8); osnažiti suradnju i partnerstvo (9) i raditi kako bismo stvarali veću socijalnu i političku volju (10).

Tim pristupom sama struktura Deklaracije navodi na zaključak da su sve točke jednim dijelom pisane kao obvezujuće za sve koji se bave dobrobiti djece i rade za nju te su također vrlo vrijedne smjernice za rad profesionalnih međunarodnih organizacija pomoću kojih se mogu kreirati agende vezane uz zaštitu dječjih prava na svim razinama. Dinamičnim pristupom autori Panamske deklaracije naglašavaju sve što je potrebno za uspješno djelovanje u području zaštite djeteta i jasno ističu važnost svake od navedenih točaka te su uspješno iskristalizirali najvažnije smjernice za tu međunarodno važnu temu. Idealno mjesto za odrastanje u okolnostima povjerenja s ljudima koji se brinu o djeci i koji ih vole jest obitelj, no nažalost, istina je također kako je obitelj ujedno i mjesto gdje se i događa najveći broj zlostavljanja. ${ }^{34}$

\subsection{Sistemski PRISTUP RimSKe DEKLARACIJE}

U Rimskoj deklaraciji Child Dignity in the Digital World navodi se kako je problem moguće riješiti kada se zajedničkim snagama udruže vlade, vjere, religije, internacionalne organizacije, tehnološka industrija, akademska i istraživačka zajednica, civilno društvo, poduzeća i sve institucije u jednome cilju: braniti dostojanstvo djece i odraslih ranjivih u digitalnome svijetu. Deklaracija je nastala kao plod Svjetskoga kongresa Child Dignity in the Digital World koji su organizirali Centar za zaštitu djece Papinskoga sveučilišta Gregoriana, WePROTECT Global Alliance i SOS Il Telefono Azzurro Onlus, a na kongresu su bili svjetski lideri iz područja religije, znanosti, društvenoga života i vlada (ili parlamenti). Cilj je stvoriti siguran digitalni svijet i okruženje u kojem su djeca i ranjivi odrasli poštovani i slobodni ostvarivati svoja digitalna prava te gdje su zaštićeni od iskorištavanja i zlostavljanja.

Rimska deklaracija po svojoj strukturi i namjeri odgovara sistemskom pristupu, u smislu da se radi dobrobiti djece u digitalnom svijetu obraća različitim, većim i manjim, globalnim i lokalnim sustavima, odnosno sistemima: svjetskim liderima (1), liderima svjetskih religija (2), parlamentima svijeta (3), liderima tehnoloških kompanija (4), svjetskim ministrima javnoga zdravstva (5), vladinim udruženjima, civilnim društvima i zakonodavnim ustanovama (6), svjetskim zakonodavno-pravnim (law enforcement) organizacijama (7), svjetskim zdravstvenim institucijama (8), vladinim i privatnim institucijama (9), vodećim autoritetima javnoga zdrav-

${ }^{34}$ Panamska deklaracija, dostupno na: https://ika.hkm.hr/dokumenti/panamska-deklaracija/ (6. 7. 2020.). 
stva (10), liderima svjetskih vlada, zakonodavnim tijelima, privatnim industrijama i religioznim institucijama (11), vladama, privatnim institucijama i religioznim institucijama (12) te ponovno vladama, privatnim institucijama i religioznim institucijama s proširenim zadaćama (13).

Takvim pristupom Rimska deklaracija obraća se onima koji bi trebali udruženo i kontinuirano raditi radi zaštite djece, dječjih prava i njihova dostojanstva, posebice $\mathrm{u}$ digitalnom novomedijskom okruženju. Potpisnici Deklaracije jasno navode tko bi se sve trebao baviti navedenim pitanjima te na taj način upućuju sve organizacije na globalnoj razini na još veći doprinos u nastojanjima za zaštitu djece. Značajno je primijetiti kako i Rimska deklaracija ističe važnost buđenja svijesti obitelji, okoline, zajednice širom svijeta, ali i same djece o realnosti učinka interneta na djecu. Najdublje tragove ostavljaju na djecu njihovi roditelji, a svoje vještine tijekom djetinjstva djeca uz podršku roditelja nastavljaju graditi kroz odnose s vršnjacima te drugim važnim osobama i skupinama koje su dio njihova socijalnoga okruženja. ${ }^{35}$ Stoga ponovno ističemo važnost povezivanja svih sustava koji su uključeni u odgoj i obrazovanje djece.

\section{Odraz i odjek pojma djeteta u Panamskoj i Rimskoj deklaraciji}

U prethodnim dijelovima pojašnjeni su različiti pristupi koje su opisale i približile Panamska i Rimska deklaracija, donesene iste godine. One su pozvale sve dionike na sustavno djelovanje pri rješavanju pitanja vezanih uz zaštitu dječjih prava, dostojanstva te prevenciju i suzbijanje svih posljedica koje dijete može osjetiti i koje mogu znatno narušiti njegovo odrastanje, posebice u području zlostavljanja, narušavanja dostojanstva, izrabljivanja i otuđenja. Ako bi se načela tih dviju vrijednih deklaracija zajednički usvojila i koristila se na svim navedenim razinama, dinamičnim pristupom Panamske deklaracije i sistemskim Rimske deklaracije dobio bi se cjelovit prikaz kako bi učinkovita, kontinuirana i profesionalna zaštita djece i njihovih prava trebala izgledati te tko bi bili glavni akteri i što bi trebali činiti. Spojem tih deklaracija dobiva se jasna slika na čemu je sve potrebno poraditi u digitalnom dobu i svijetu u kojem djeca iz različitih konteksta iz kojih dolaze trebaju biti zaštićena, ali i upoznata sa svojim pravima i autoritetima (osobama i institucijama) koje ih kontinuirano štite.

Dva pristupa - dinamični i sistemski - koji su korišteni u Panamskoj i Rimskoj deklaraciji mogu se razumjeti i kroz metaforu ogledala i jeke, a njihov sadržaj kao odraz i odjek kako bi se djeca i njihova prava trebala štititi i kako bi njihov položaj

${ }^{35}$ Usp. D. KRALJ, R. ĆORIĆ-ŠPOLJAR, Socijalno kompetentno dijete, u: G. BULJAN FLANDER i suradnici (ur.), Znanost i umjetnost odgoja - Praktični priručnik o suvremenom odgoju za roditelje $i$ odgojitelje, Sveta Nedjelja, 2018., 419-438. 
u novomedijskom okruženju, odgojnim ustanovama, religioznom i obiteljskom kontekstu trebao izgledati u cijelom svijetu, uključujući sva njihova obilježja, različitosti i razine na kojima se njihova prava štite ili bi se trebala štititi. Povezivanjem točaka Panamske deklaracije, koja jasno navodi kako bi se djeca trebala štititi, te točaka Rimske deklaracije, koja navodi tko bi trebao djecu štititi odgovornim, sustavnim i cjelovitim pristupom, dobiva se sveobuhvatna slika o položaju djeteta u digitalnom i suvremenom svijetu te slika o svim potrebama nužnim za njihovo sigurno odrastanje.

Učinkovitost rada na dobrobiti djece možemo vidjeti u usklađenom i nadopunjavajućem pristupu i Panamske i Rimske deklaracije. Po samom naslovu Panamska deklaracija ističe nakanu borbe za iskorjenjivanje nasilja nad djecom i prema djeci, dok Rimska deklaracija u naslovu ističe općevažeću vrijednost dostojanstva djece $\mathrm{u}$ digitalnom svijetu. Oba naslova govore o dvjema nogama hoda prema ostvarenju dobrobiti djece u svijetu, odnosno borbe protiv nasilja nad djecom, te s druge strane isticanja i rada na dostojanstvu djece u svijetu. Pomoći djeci stati na vlastite noge, osamostaliti $\mathrm{se}^{36}$, cilj je mnogih psihološko-pedagoških nastojanja i samoga procesa odgoja.

Zajedničkim snagama (Rimska deklaracija), uključujući velike i male sustave, želi se osigurati, povećati, odgajati, dogovarati, ojačati, identificirati i dovesti, prihvatiti, osnažiti, raditi (Panamska deklaracija), sve radi dobrobiti djece. Zlostavljanje i iskorištavanje djece događa se, nažalost, planirano, pa je stoga i zaštita djece moguća ako se zajedničkim snagama traži, promiče, gradi dobro.

\section{Bog i dostojanstvo djece}

U judeokršćanskoj baštini, kada govorimo o dostojanstvu djece, vrlo važnim nam se čini spomenuti Hagaru i njezina sina Jišmaela, kojega je začela s Abramom (Post 16 , 4). Naime, budući da Sara, Abramova žena, nije rađala djecu, ona je svoga muža Abrama poslala k svojoj sluškinji Hagari, koja je začela dijete. No vrlo brzo Hagara odlazi u pustinju jer je Sara vrlo loše prema njoj postupala. Ondje je Bog po anđelu susreće kod vrela/izvora (Post 16, 7). U susretu Hagare i anđela važno je naglasiti, s obzirom na naš članak, kako joj anđeo Gospodnji u tom trenutku obećava da će umnožiti njezino potomstvo (Post 16, 10). No još je važnije što joj anđeo Gospodnji govori kako će se dijete zvati Jišmael [»Nadjeni mu ime Jišmael (Bog čuje)《

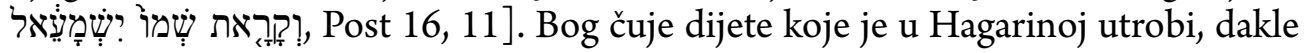
Bog vidi ono što je i skriveno, što je po sebi nečujno. Drugi važan korak za Hagaru jest, što nam sveti pisci donose, da je Boga koji joj je govorio i ona sama nazvala El

${ }^{36}$ J. STEWART, V. JOINES, A New Indroduction to Transactional Analysis. 


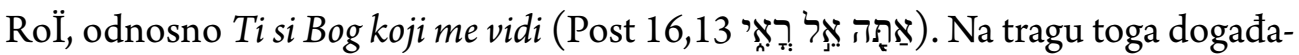
ja iz Knjige Postanka, gdje se Bog zauzima za trudnu ženu, odnosno za ženu i dijete u njoj, iako sama Hagara to ne traži, zaključujemo kako je Bog onaj koji vidi ono što čovjek ne vidi, čuje ono što čovjek ne čuje. ${ }^{37}$ Zauzeti se za slabe, siromašne, neviđene nije samo krajnji cilj judeokršćanske antropologije nego također i drugih svjetskih religija. Takvim postupanjem otvara se mogućnost za sve koji djeluju na području zaštite djece da steknu Hagarino iskustvo, odnosno da ispovijedaju s njom: Ti si Bog koji me vidi. Takav pogled vraća dostojanstvo djeci, a svi koji se zauzimaju za dobro djece postaju baštinici Božjega obećanja da ćemo imati potomstvo, odnosno nastaviti živjeti.

U zaštiti dostojanstva djece potreban je savez među raznim institucijama jer djeca danas žive u svijetu u kojem je nemoguće preživjeti ako se ne ujedinimo i povežemo u zaštiti dobra i dostojanstva. To je iskustvo koje nam Sveto pismo donosi, kako smo vidjeli, već od samoga početka ${ }^{38}$, ali također i potreba oslanjanja na Boga koji je sklopio Savez sa svojim narodom (Ez 18, 8-16; Pnz 8, 18). To je stvarnost koja povezuje i te dvije deklaracije. Naime obje su nastale, osim u znanstvenom, također i u religijskom, odnosno vjerskom kontekstu te su nam i one potvrda kako vjera i razum idu zajedno (Fides et ratio). Prema Katekizmu Katoličke Crkve (br. 2378):

$\gg$ Dijete nije neki dug, nego dar. 'Najuzvišeniji dar braka', jest ljuska osoba. Dijete se ne može smatrati objektom vlasništva, čemu bi moglo voditi priznavanje nekoga tobožnjeg 'prava na dijete'. Na tom području samo dijete posjeduje istinska prava, to jest 'da bude plod posebnog čina bračne ljubavi svojih roditelja kao i pravo da bude poštivano kao osoba od trenutka svoga začeća. «

\section{Pitanje zla i grijeha u zlostavljanju i iskorištavanju djece}

Cilj je spomenutih deklaracija zaštita dobrobiti djece pred nasiljem, no ovdje želimo spomenuti i zaštitu djece od zla. Pitanje zla već se godinama u psihijatriji izbjegava, no i u psihologiji se pitanje zla vrlo malo istražuje. ${ }^{39}$

Osobe koje čine zlo one to planiraju, smišljaju, odnosno unaprijed gledaju kako svjesno i namjerno nanijeti zlo drugima. Također autor Haller citira Wilhelma Buscha rečenicom: »Das Gute, dieser Satz steht fest, ist stets das Böse, was man lässt«,

${ }^{37}$ C. WÜSTE, Eine Frau findet Gottes Namen, u: Bibel heute 1(2018.)213, 12-13.

${ }^{38}$ PONTIFICA COMMISSIONE BIBLICA, Che cosa è l'uomo. Un itinerario di antropologia biblica, Rim, 2019.

${ }^{39}$ R. HALLER, Das Böse: Die Psychologie der menschlichen Destruktivität, Wals bei Salzburg, 2019. 
odnosno: »Dobro je, ovo je sigurno tako, stalno zlo, što se propusti učiniti.« ${ }^{40} \mathrm{Ipak}$, postoji i druga perspektiva činjenja zla, a to je nesvjesno i/ili nenamjerno zlo koje osobe mogu činiti. Takva percepcija potječe još od Platonova doba, posebice njegova spisa, odnosno dijaloga Protagora. Prema toj percepciji, zlo se može načiniti nenamjerno zbog nedovoljnoga poznavanja druge osobe, njezine reakcije na obrasce ponašanja drugih prema njima, nepoznavanja empatije ili neposjedovanja empatije, što može rezultirati nanošenjem psiholoških posljedica, iako to nije bila prvotna namjera niti se planirala i smišljala unaprijed prema drugoj osobi.

S druge strane i u Rimskoj i u Panamskoj deklaraciji planira se dobro, planira se dobro među sustavima, ali isto tako planira se dobro naglašavajući ono što je potrebno plemenito učiniti. To je protivno zlomu. Na grčkome zlo, $\delta$ เá $\beta o \lambda o \varsigma^{41}$, đavao jest onaj koji razbacuje, koji raspršuje. Zlo je ono koje ima raspršujući, razjedinjujući, dezintegrirajući učinak. Rimska deklaracija upravo naglašava povezanost, suprotnost raspršivanju, i manjih i većih sustava u borbi protiv zla nad djecom.

Haller definira zlo kao ono djelovanje koje se čini slobodnom voljom, izbjegavajući $\gg$ moralni instinkt $\ll$, te se na agresivan način usmjerava protiv tjelesnoga, psihičkoga ili društvenoga integriteta drugih. ${ }^{42}$ Papa Franjo govori kako net/mreža ima tamnu stranu (dark net) gdje zlo pronalazi uvijek nove, učinkovite i prožimajuće putove djelovanja i širenja. ${ }^{43}$ Tim više upravo zaštita dostojanstva djece treba imati planirane, dugoročne, smišljene, organizirane dobre i plemenite načine djelovanja, računajući pri tome i na utjecaj zla u borbi za dobro.

Svijet u kojem živimo, čitamo u Katekizmu Katoličke Crkve (br. 164), čini se često veoma daleko od onoga u čemu nam vjera pruža sigurnost; iskustva zla i patnje, nepravdi i smrti kao da proturječe Radosnoj vijesti. Sve to može uzdrmati vjeru i staviti je na kušnju. Djelovanje zla može nas staviti na kušnju i obeshrabriti u djelovanju i promicanju zaštite i dostojanstva djeteta, no s druge strane i dodatno osnažiti i potaknuti kroz dugoročne planove, zajedničko-sistemskim djelovanjem, graditi i stvarati sigurna mjesta za djecu.

Učinak pak zla jest grijeh. I ovdje je korisno istaknuti značenje riječi grijeh á $\mu \alpha \rho \tau i ́ \alpha$ $(\alpha \varsigma, \grave{\eta})$ na grčkom jeziku, odnosno doslovni prijevod glasi promašiti cilj. ${ }^{44}$ Vrhunac

\footnotetext{
${ }^{40}$ R. HALLER, Das Böse: Die Psychologie der menschlichen Destruktivität, 23.

${ }^{41}$ https://biblehub.com/greek/1228.htm (5. 7.2020.).

${ }^{42}$ R. HALLER, Das Böse: Die Psychologie der menschlichen Destruktivität.

${ }^{43}$ FRANJO, Govor pape Franje sudionicima kongresa Dostojanstvo djece u digitalnom svijetu, svibanj 2017. Dostupno na: http://www.vatican.va/content/francesco/en/speeches/2019/november / documents/papa-francesco_20191114_convegno-child\%20dignity.html (6. 7. 2020.).

${ }^{44}$ Dostupno na: https://biblehub.com/greek/266.htm (13. 7. 2020.).
} 
preventivno-edukativnoga procesa u zaštiti djece bio bi pomoći i dovesti počinitelje zlostavljanja, iskorištavanja do svijesti kako su promašili cilj svoga djelovanja te, u konačnici, i postojanja. Takav proces ide paralelno i sa zakonskim nošenjem posljedica za počinitelja koje mogu pomoći i pri osvještavanju počinjenoga zla djela. Ponovno prema KKC-u (br. 1849): »( ... grijeh je prekršaj protiv razuma, istine, ispravne savjesti; prijestup je istinske ljubavi prema Bogu i bližnjemu, zbog izopačene privrženosti nekim dobrima. On ranjava čovjekovu narav i ugrožava ljudsku solidarnost; definiran je kao 'riječ, čin ili želja protiv vječnoga zakona'« Grijeh, posljedica zla, ranjava prije svega one koji ga čine, a potom i one koji su ranjeni postupcima drugih. Lijek za posljedice zla i grijeha jest, u konačnici, Božja milost, milosrđe koje se ostvaruje upravo u brizi za one koji su najranjiviji i najnezaštićeniji članovi sveopće ljudske obitelji, odnosno djecu. Ako posljednju rečenicu lijeka kroz Božje milosrđe svedemo u ljudske okvire sadašnjega trenutka, dakako da se svakom ponašanju štetnomu za djecu koje im počinitelj nanese treba pružiti profesionalna pomoć - i žrtvi i počinitelju. No sveobuhvatniji pogled i svojevrsno rješenje nanošenja zla i bilo kojega oblika štete djetetu jest u prevenciji, a ne svojevrsnom gašenju požara kada već do zakonski zabranjenoga i osuđujućega nanošenja štete dođe, jednako kao i ponavljajućih štetnih obrazaca ponašanja prema djeci. Prije zaključka, možemo se osvrnuti na dio Matejeva evanđelja: »Zaista, kažem vam, što god ne učiniste jednomu od ovih najmanjih, ni meni ne učiniste.« (Mt $25,45)$

\section{Zaključak}

Svoju svrhu i učinak Panamska i Rimska deklaracija ostvarit će onoliko koliko se načela budu primjenjivala u praksi. Ona su svojevrsni putokaz za mnoge institucije i sisteme, odnosno sustave koji svoju pozornost, brigu, stručnost, znanje usmjeravaju na djecu, dječja prava, njihovu zaštitu, kao i preveniranje posljedica. Zajedničkim snagama različitih sustava, interdisciplinarnim pristupima u znanosti, trudom i ulaganjem stručnjaka otvara se prostor razvijanju osjetljivijega mentaliteta prema nezaštićenim skupinama društva, među kojima su i djeca. Panamska i Rimska deklaracija pokazuju nam tko i na koji način, odnosno kako može doprinijeti blagostanju djece, ali i odraslih u svijetu, i u civilnom društvu i u religioznom kontekstu. Važnost te teme pokazuju i brojne inicijative međunarodnih organizacija, vrijedna djelovanja Katoličke Crkve i cjelokupnoga nauka, kao i zakonodavno-pravnih akata koji su usmjereni upravo na cilj zaštite djeteta. Poput Levinasove etike Drugoga i u ovom kontekstu možemo govoriti o etici Djeteta naglašavajući njegovu važnost velikim početnim slovom. Uloga i važnost djece u društvu, kao i promicanje i zaštita njihovih prava područja su koja su prepoznata na različitim razinama. Kao najvažnije možemo istaknuti nekoliko govora pape Ivana Pavla II., razne inicijative pape 
Benedikta XVI. i pape Franje, zatim Panamsku i Rimsku deklaraciju, kontinuirana djelovanja i inicijative pokrenute kroz projekte UNICEF-a, Ujedinjenih naroda, kao i Poliklinike za zaštitu djece grada Zagreba. Sve to jasan je pokazatelj važnosti sustavnoga, cjelovitoga, kontinuiranoga i umreženoga proučavanja, istraživanja i djelovanja na svim društvenim razinama. Odnos prema djeci ogled je i odjek društva, osobito demokratskoga. U skladu s navedenim napredak takvoga društva odražava se u odnosu koji društvo ima prema djeci. Dvije deklaracije, kao temelji ovoga rada, pokazatelj su napretka društva i višegodišnjih napora u promicanju te teme. 


\title{
A REFLECTION AND ECHO OF THE PROTECTION AND SAFER FUTURE OF THE CHILD IN THE LIGHT OF PANAMA AND ROME DECLARATIONS
}

\author{
Josip BOŠNJAKOVIĆ* - Leali OSMANČEVIĆ $* *$
}

Summary: Children and children's rights are an extremely important topic in the scientific research and practical field of communication sciences, psychology, and theological considerations. This topic is the main focus of the universal service of religious and international institutions and associations, while legislative and legal frameworks are created every year, protecting children and their general existence in the world, advocating equality. Thus, in 2017, two very important declarations were accepted: the Panama Declaration and the Rome Declaration. This paper will address the topic of children and children's rights in the light of communication sciences, theology, and psychology, together with relevant documents, and will analyze different approaches to these declarations. The contribution of this paper is a comprehensive presentation of the topic of children's rights through the prism of these declarations, which is also the first analysis of these two declarations that protect children's rights and dignity, and a safer future at an international level.

Keywords: children, dignity, protection, Panama Declaration, Rome Declaration, children's rights.

\footnotetext{
* Asst. Prof. Josip Bošnjaković, Ph. D., Catholic Faculty of Theology in Đakovo, J. J. Strossmayer University of Osijek, Petra Preradovića 17, P. O. box 54, 31400 Đakovo, Croatia - Catholic University of Croatia, Ilica 242, 10000 Zagreb, Croatia, josip.bosnjakovic@djkbf.hr

** Leali Osmančević, Mag. Comm., Catholic University of Croatia, Ilica 242, 10000 Zagreb, Croatia, leali.osmancevic@unicath.hr
} 